\title{
Contribution of Tumor Necrosis Factor to Host Defense against Staphylococci in a Guinea Pig Model of Foreign Body Infections
}

\author{
Pierre Vaudaux, Georges E. Grau, Elzbieta Huggler, \\ Françoise Schumacher-Perdreau, Franz Fiedler, \\ Francis A. Waldvogel, and Daniel P. Lew
}

\author{
Division of Infectious Diseases, Department of Medicine. University \\ Hospital, and Department of Pathology, University of Geneva. \\ Switzerland; Instiute of Hygiene and Microbiology, University of \\ Cologne, and Institute of Genetics and Microbiolog:. \\ University of Munich, Germany
}

\begin{abstract}
The contribution of the cytokine tumor necrosis factor (cachectin; TNF) to host defenses against staphylococcal foreign body infections was studied in vivo. In tissue cages subcutaneously implanted into guinea pigs, progressive infection was initiated by a very low inoculum (100 cfu) of Staphylococcus aureus with a success rate of $100 \%$, as is frequently encountered in related clinical situations. Locally injected autologous bacterial components derived from the cell wall of $S$. aureus, in particular peptidoglycan, were very active in raising TNF levels in tissue cage fluid and in preventing the development of infection by the $100 \%$ infective dose of the test strain. Furthermore, injection of murine recombinant TNF into tissue cages could substitute for the bacterial components in preventing experimental infection by $S$. aureus. The protective effect of TNF-eliciting bacterial components could be neutralized by anti-TNF antibodies. $A$ local increase in TNF levels might improve host defenses against staphylococcal foreign body infections.
\end{abstract}

Staphylococcal foreign body infections are a major source of patient morbidity and implant failure. Not only strains of Staphylococcus aureus endowed with numerous virulence determinants but also species of coagulase-negative staphylococci previously considered nonpathogenic are recovered on infected orthopedic prostheses or cardiovascular devices [ 1 , 2]. Animal models have confirmed the high susceptibility of artificial implants to low inocula of staphylococci [3-5], even of weakly virulent strains. These observations confirmed the ineffectiveness of local host defense mechanisms against microorganisms colonizing the implants [2-5].

In a previously developed guinea pig model of foreign body infection, we have shown that progressive infection was regularly produced by a very low inoculum $\left(10^{2} \mathrm{cfu}\right)$ of $S$. aureus Wood 46 in subcutaneously implanted tissue cages [4]. In contrast, the same strain was unable to cause significant infection when injected subcutaneously or intraperitoneally at an inoculum as high as $10^{8} \mathrm{cfu}$ in the absence of tissue cages $[2,4]$. Significant defects in the phagocytic and bactericidal functions $[2,4,5]$ of polymorphonuclear leukocytes were observed in the infected tissue cage fluid, an inflammatory exudate elicited by the subcutaneous implant.

Received 13 November 1991: revised 13 February 1992

Presented in part: 25 th and 29th Interscience Conferences on Antimicrobial Agents and Chemotherapy (September-October 1985. Minneapolis. abstract 109; September 1989. Houston, abstract 331)

Grant support: Swiss National Research Foundation (32-30161.90) and Sandoz Research Foundation.

Reprints or correspondence: Dr. Pierre Vaudaux. Division of Infectious Diseases, University Hospital, 1211 Geneva 4, Switzerland.

The Journal of Infectious Diseases 1992;166:58-64

(C) 1992 by The University of Chicago. All rights reserved. $0022-1899 / 92 / 6601-0009 \$ 01.00$
In preliminary observations [6], we have shown that locally injected bacterial factors obtained from a laboratory strain of $S$. aureus could prevent experimental infection by the same strain. A number of recent studies [7-20] have shown that host production of cytokines by either nonimmune cells (fibroblasts, endothelial cells) or cells of the immune system $[7,8]$ significantly contributes to host defense against various pathogens $[9-11]$. One of the most potent cytokines is tumor necrosis factor (cachectin; TNF); its production by mononuclear phagocytes [ 7,12$]$ is strongly stimulated by bacterial endotoxin (lipopolysaccharide [LPS]) from gram-negative organisms $[7,12,13]$ or by either fixed or heat-killed staphylococcal whole cells [14, 18]. Whereas several studies have focused on the pathophysiologic effects of circulating levels of TNF or other cytokines during gramnegative and -positive [14] bacteremic infections, none has reported in detail how cytokine release might contribute to host defense against staphylococcal infections. Furthermore, the precise contribution of different cell wall or membrane components of staphylococci or other gram-positive bacteria $[19,20]$ as inducers of TNF release is not entirely elucidated.

We investigated whether injecting staphylococcal cell wall components into an experimental model of staphylococcal foreign body infection could elicit strong local production of TNF and determined the effects of this increased production of TNF on host susceptibility to experimental $S$. aureus infection.

\section{Materials and Methods}

\section{Tissue Cage Implantation}

Rigid perforated polytetrafluoroethylene (Teflon) tubes (internal and external diameters, 10 and $12 \mathrm{~mm}$, respectively: 
length, $32 \mathrm{~mm}$ ) were implanted subcutaneously in to guinea pigs as previously described [4]. Animąls were used for further experimentation 3-6 weeks after tissue cage implantation. An important characteristic of this model is that the perforations permit ingress of inflammatory cells into tissue cage fluid, in particular polymorphonuclear neutrophils and monocytes as previously described in detail [4].

\section{Preparation of Soluble Bacterial Factors}

Crude lysate. One liter of an overnight culture of $S$. aureus Wood 46 in Mueller-Hinton broth was washed and suspended in $10 \mathrm{ml}$ of PBS (GIBCO, Paisley, Scotland). The concentrated suspension $\left(10^{11}\right.$ cells $\left./ \mathrm{ml}\right)$ was then lysed for $2 \mathrm{~h}$ at $37^{\circ} \mathrm{C}$ with a mixture of lysostaphin (10 units/ml; Sigma, St. Louis), DNase $(10 \mu \mathrm{g} / \mathrm{ml}$; Sigma $)$, and RNAse $(10 \mu \mathrm{g} / \mathrm{ml}$, Sigma $)$ by a modification of a previously published procedure [21]. Thereafter, the enzymes in the bacterial lysate were inactivated by heating at $90^{\circ} \mathrm{C}$ for $30 \mathrm{~min}[21]$. The lysate was cleared from particulate material by two sequential centrifugations at $3000 \mathrm{~g}$ for $30 \mathrm{~min}$ and $100,000 \mathrm{~g}$ for $60 \mathrm{~min}$, respectively. The protein content of the solubilized factors ranged from 250 to $520 \mu \mathrm{g} / \mathrm{ml}$, as estimated by protein assay (Bio-Rad Laboratories, Munich). Each preparation was checked for complete heat inactivation of lysostaphin activity by showing the absence of lethal effect on exponentially growing test organisms. Accordingly, $10^{6} \mathrm{cfu}$ of $S$. aureus Wood 46 was incubated in vitro at $37^{\circ} \mathrm{C}$ for $60 \mathrm{~min}$ in a $1-\mathrm{ml}$ mixture containing $400 \mu \mathrm{l}$ of PBS, $250 \mu \mathrm{l}$ of tissue cage fluid, and $250 \mu 1$ of either solubilized bacterial factors or PBS as a control, and viable counts were made at 0 and $60 \mathrm{~min}$.

Partially purified factors. The prophylactically active soluble factors were partially purified from the bacterial lysate by extraction with an equal volume of $10 \%$ trichloroacetic acid (TCA) for $2 \mathrm{~h}$ at $4^{\circ} \mathrm{C}$. About $99 \%$ of the protein components of the bacterial lysate were precipitated by TCA and removed by low-speed centrifugation, as estimated by the Bio-Rad assay. Thereafter, the TCA-solubilized bacterial components were concentrated by overnight precipitation at $4^{\circ} \mathrm{C}$ with 5 vol of $100 \%$ ethanol followed by low-speed centrifugation. This ethanol precipitate was solubilized in PBS and dialyzed overnight at $4^{\circ} \mathrm{C}$ against PBS to remove traces of TCA, in membrane tubing (Spectrapor; Spectrum, Los Angeles) with a molecular weight cutoff of 12,000-14,000. Efficient removal of TCA was assessed by checking the $\mathrm{pH}$ of the final solution of partly purified bacterial factors; a value of 7.2 was usual.

Purified cell walls. Purified cell walls of S. aureus Wood 46 were prepared as described [22]. Briefly, after inactivation of autolytic enzymes by heat treatment $\left(20 \mathrm{~min}, 100^{\circ} \mathrm{C}\right)$, cells were disrupted with glass beads and the cell debris separated by centrifugation for $20 \mathrm{~min}$ at $20,000 \mathrm{~g}$. After washing once with distilled water, membrane residues were removed by treatment with $1 \%$ Triton $\mathrm{X}-100$ for $30 \mathrm{~min}$ at $30^{\circ} \mathrm{C}$, and the crude cell wall was thoroughly washed (four times) with distilled water. Crude cell wall was further depleted of contaminating proteins by extensive proteolytic digestion with $0.5 \mathrm{mg} / \mathrm{ml}$ trypsin for 16 $\mathrm{h}$ at $37^{\circ} \mathrm{C}$ in $0.05 \mathrm{M}$ phosphate buffer at $\mathrm{pH} 7.8$, washed five times with distilled water, and lyophilized. Quantitative analysis of the cell wall preparation was done after hydrolysis with $4 \mathrm{~N}$
$\mathrm{HCl}$ for $16 \mathrm{~h}$ at $100^{\circ} \mathrm{C}$ and showed minimal contamination $(<5 \%)$ by amino acids other than those normally found in peptidoglycan $[22,23]$. Compared to glutamic acid, the molar ratios of major cell wall amino sugars and amino acids were 0.98 for muramic acid, 1.91 for glucosamine, 2.05 for alanine, 1.18 for lysine, 3.81 for glycine, and 0.16 for serine.

To solubilize prophylactically active components, we incubated a $1-\mathrm{mg} / \mathrm{ml}$ suspension of purified cell walls with lysostaphin, DNase, and RNase as above. After $2 \mathrm{~h}$, the preparation was also heated for enzyme inactivation as described above, centrifuged at $100,000 \mathrm{~g}$ for $60 \mathrm{~min}$ to remove unsolubilized material, and stored at $-20^{\circ} \mathrm{C}$.

Cell wall teichoic acid and peptidoglycan. Ribitol teichoic acid was purified by extraction of undigested, purified cell walls $\left(5 \mathrm{mg} / \mathrm{ml}\right.$ ) with $10 \%$ TCA for $72 \mathrm{~h}$ at $4^{\circ} \mathrm{C}$, with occasional stirring [24]. After centrifugation at $20,000 \mathrm{~g}$ for $20 \mathrm{~min}$ at $4^{\circ} \mathrm{C}$, the TCA-solubilized teichoic acid was concentrated by precipitation with 5 vol of cold ethanol. After centrifugation, the teichoic acid precipitate was redissolved in 10\% TCA and reprecipitated with 5 vol of cold ethanol, then solubilized in water and lyophilized. The phosphate content of purified teichoic acid was $300 \mu \mathrm{g} / \mathrm{mg}$ as determined by a colorimetric assay [25].

The TCA-insoluble peptidoglycan component of cell walls was concentrated by centrifugation, then washed repeatedly with distilled water and lyophilized. Unlike purified teichoic acid, TCA-purified peptidoglycan had a residual phosphate content of only $30.6 \mu \mathrm{g} / \mathrm{mg}$, which indicated a low level of contamination by teichoic acid incompletely extracted by TCA. Quantitative analysis of TCA-purified peptidoglycan, after hydrolysis with $4 \mathrm{~N} \mathrm{HCl}$ for $16 \mathrm{~h}$ at $100^{\circ} \mathrm{C}$, showed a shift in the molar ratio of glucosamine to glutamic acid from 1.98 before TCA extraction of cell walls to 0.93 after TCA extraction. In addition, TCA-purified peptidoglycan [25] contained molar ratios of alanine, glycine, lysine, and serine equivalent to those assayed in purified cell walls [26].

To test the biological properties of teichoic acid-free peptidoglycan, we prepared this purified component by an alternative procedure, namely by releasing ribitol teichoic acid from undigested, purified cell walls treated with $60 \%$ hydrofluoride (Riedel-de Haen, Seelze, Germany) as described previously [27, 28]. The phosphorus and ribitol content of peptidoglycan purified by this procedure was reduced to $<5 \%$ compared with trypsinized cell walls. Consequently, glucosamine was present in the amount that corresponds to peptidoglycan. Analysis of the amino acids and amino sugars clearly indicated that the peptidoglycan was not changed by treatment with hydrofluoride.

\section{Screening for Endotoxin and Exotoxin Contamination}

Preparations of bacterial components were systematically screened to exclude significant endotoxin contamination, as assayed by the Limulus amebocyte lysate test (sensitivity, $10 \mathrm{pg} /$ $\mathrm{ml}$; Associates of Cape Cod, Woods Hole, MA), and none contained detectable endotoxin. In addition, since recent studies also showed that a number of staphylococcal exotoxins could induce TNF production, we had to exclude their contribution in the preparations. The possible presence of staphylococcal enterotoxins was investigated by an ELISA (type A-B-C-D; Bommerli 
Laboratories, Bern, Switzerland) according to the manufacturer. None of these enterotoxins was produced by $S$. aureus Wood 46 (limit of detection of the test, $0.1-1 \mathrm{ng} / \mathrm{ml}$ ). Toxic shock syndrome toxin (TSST)-1 was determined serologically by gel diffusion [29]. Although TSST-1 production was demonstrated in supernatants of $S$. aureus Wood 46 cultures, this activity was consistently absent from purified cell walls or their purified components. Finally, the presence of staphylococcal $\alpha$-toxin, of which $S$. aureus Wood 46 is a rich producer, was also screened for by a hemolytic assay against rabbit erythrocytes as previously described [30]. None of the preparations showed any significant hemolytic activity.

\section{Experimental Infections and Protection Experiments}

S. aureus Wood 46 , a protein A-deficient strain, was used as the infecting microorganism for experimental tissue cage infection $[4,5]$. Occasionally, $S$. aureus Cowan I, a protein A-rich strain, or Staphylococcus epidermidis KH 1I, a clinical isolate from a catheter-related sepsis [31], were used. Overnight cultures of bacteria in Mueller-Hinton broth were washed and resuspended in $0.9 \% \mathrm{NaCl}$. Tissue cages were inoculated with $0.2 \mathrm{ml}$ of a $10^{-7}$ dilution, which usually contained $0.8-1.2 \times 10^{2} \mathrm{cfu} /$ $\mathrm{ml}$, as checked by plating on Mueller-Hinton agar.

The prophylactic administration of bacterial components was done by local inoculation of $0.5 \mathrm{ml}$ (except when indicated) of the various preparations in 3 of 4 tissue cages per animal, at 2-3 $\mathrm{h}$ (except when indicated) before inoculation of live $S$. aureus. In addition, 1 tissue cage received $0.5 \mathrm{ml}$ of sterile nonpyrogenic saline as a control. Frozen aliquots of enzymatically solubilized bacterial components, derived from either whole cell lysates or purified cell walls, were thawed just before use.

When purified ribitol teichoic acid or either TCA- or hydrofluoride-purified peptidoglycan were tested, they were not enzymatically solubilized. Instead, $1 \mathrm{mg}$ from stored lyophilized preparations was freshly suspended in $1 \mathrm{ml}$ of PBS by sonication for $15 \mathrm{~s}$ with a microsonicator (Branson sonifier 250, Danbury, CT) before being serially diluted for injection into tissue cages.

Experimental infection or protection was evaluated by quantitative bacterial cultures in aspirated tissue cage fluid (minimal detection level, $10 \mathrm{cfu}$ ) [4, 6]. Tissue cage fluid showing no growth $(<10 \mathrm{cfu} / \mathrm{ml})$ at 24 and $48 \mathrm{~h}$ after inoculation was scored as protected [6].

\section{In Vivo Production of TNF}

Routinely, a $0.2-\mathrm{ml}$ sample of tissue cage fluid was aspirated to assay the baseline level of TNF just before prophylactic administration of the bacterial components (or control saline) into tissue cages. At $2 \mathrm{~h}$, a second aspiration was done to assay the TNF level just before injection of $S$. aureus Wood 46. TNF levels were also evaluated after $24 \mathrm{~h}$ in tissue cages with culturenegative fluids. TNF activity in tissue cage fluid samples was measured using a cytolytic crystal violet assay with actinomycin D $(1 \mu \mathrm{g} / \mathrm{ml})$-treated L929 cells (obtained from R. Ulevitch. Scripps Clinic, San Diego) as described previously [32]. Results were expressed in units per milliliter, 1 unit being defined as the reciprocal of the dilution leading to $50 \%$ lysis [32]. The reproduc-
Table 1. Prevention of staphylococcal tissue cage infection by local injection of soluble bacterial components (whole cell lysate) of S. aureus Wood 46.

\begin{tabular}{|c|c|c|}
\hline Prophylactic substance & $\begin{array}{l}\text { No. protected/ } \\
\text { no. tested }\end{array}$ & $\begin{array}{l}\text { Protection rate } \\
\text { (\%) }\end{array}$ \\
\hline Saline & $0 / 56$ & 0 \\
\hline \multicolumn{3}{|l|}{ Whole cell lysate } \\
\hline Untreated & $26 / 26$ & 100 \\
\hline Dialyzed & $26 / 32$ & 9] \\
\hline \multicolumn{3}{|l|}{ Partially purified components* } \\
\hline Untreated & $16 / 18$ & 89 \\
\hline Trypsinized $^{\dagger}$ & $4 / 4$ & 100 \\
\hline Digested with proteinase $\mathrm{K}^{\ddagger}$ & $4 / 4$ & 100 \\
\hline
\end{tabular}

ibility of the assay was assessed by testing the susceptibility to lysis of L929 cells by a standard curve of known concentrations of recombinant murine TNF (rTNF, obtained from B. Allet, Glaxo. Geneva) (specific activity, $10^{7}$ units $/ \mathrm{ml}$ ). Basal levels in normal tissue cage fluid or serum were $<30$ units $/ \mathrm{ml}$, which was taken as the limit of specific TNF-induced cytolysis. The specificity of the cytolytic assay of guinea pig TNF was evaluated by the neutralizing effect of an anti-TNF mouse monoclonal antibody (MAb) (2A5 [IgG2a]; provided by D. Degroote, Medgenix, Fleurus, Belgium). Of many anti-human TNF MAbs, 2A5 was the only one that cross-reacted with guinea pig TNF, neutralizing 3-10 cytolytic units in the L929 assay at concentrations of $30-70 \mu \mathrm{g} / \mathrm{ml}$.

\section{Results}

Prevention of experimental foreign body infection by bacterial factors from whole cell lysates. In the control group of guinea pig tissue cages injected with saline, $100 \%$ of cages ( $n$ $=56$ ) inoculated with $0.8-1.2 \times 10^{2}$ cfu of $S$. aureus Wood 46 developed a permanent infection (table 1): Quantitative cultures of $S$. aureus in the tissue cage fluid yielded $10^{4}-10^{7}$ $\mathrm{cfu} / \mathrm{ml}$ at either 1,2 , or 5 days after inoculation. In contrast, when $0.5 \mathrm{ml}$ of soluble bacterial factors was injected into tissue cages $3 \mathrm{~h}$ before inoculation, infection was prevented in all the challenged cages $(n=26$, table 1). Control experiments verified in vitro that the bacterial lysate per se contained no residual antibacterial activity, as could have resulted from incompletely inactivated lysostaphin. The test organisms ( $S$. aureus Wood 46) incubated in vitro for $60 \mathrm{~min}$ at $37^{\circ} \mathrm{C}$ in PBS supplemented with $25 \%$ tissue cage fluid showed an increase in colony-forming unit counts of $97 \% \pm$ $36 \%$ (mean $\pm \mathrm{SD}, n=6$ ) in the presence of the soluble bacterial factors compared with $82 \% \pm 35 \%$ in their absence, thus 
Table 2. Prevention of staphylococcal tissue cage infection by local injection of bacterial components enzymatically solubilized from purified cell walls of $S$. aureus or chemically purified.

\begin{tabular}{lcc}
$\begin{array}{l}\text { Prophylactic substance. time } \\
\text { lag before challenge }\end{array}$ & $\begin{array}{c}\text { No. protected/ } \\
\text { no. tested }\end{array}$ & $\begin{array}{c}\text { Protection rate } \\
(\%)\end{array}$ \\
\hline Cell wall components & & 82 \\
$3 \mathrm{~h}$ & $9 / 11$ & 100 \\
$2 \mathrm{~h}$ & $12 / 12$ & 82 \\
$5 \mathrm{~min}$ & $9 / 11$ & 30 \\
Ribitol teichoic acid, 2 h & $3 / 10$ & 100 \\
Peptidoglycan & & 83 \\
TCA-purified, 2 h & $10 / 10$ & \\
HF-purified, 2 h & $10 / 12$ & \\
\hline
\end{tabular}

NOTE. $0.5 \mathrm{ml}$ of cell wall components or $10 \mu \mathrm{g}$ of ribitol teichoic acid or trichloroacetic acid (TCA)-or hydrofluoride (HF)-purified peptidoglycan was injected.

demonstrating that lysostaphin had been readily inactivated by heat treatment.

Early attempts to characterize the physicochemical nature of the prophylactically active bacterial components showed that they were not trypsin-sensitive surface components of $S$. aureus Wood 46, because trypsinization of the bacterial culture, done shortly before cell lysis, left intact the prophylactic activity of soluble components (data not shown). Also, the prophylactic factors were not low-molecular-weight components, since after overnight incubation in membrane tubing with a molecular weight cutoff of 12,000-14,000, undialyzed components were still active for preventing experimental infection in $91 \%(n=32)$ of challenged tissue cages (table 1). Finally, extraction of soluble components of the crude lysate with 5\% TCA followed by ethanol precipitation produced partially purified bacterial factors still showing a high prophylactic activity (table 1) despite the removal of $\sim 99 \%$ of proteins originally present in the lysate supernatant. Furthermore, this preparation of partly purified bacterial factors was not altered in its prophylactic activity by treatment with proteolytic enzymes such as trypsin or proteinase $\mathrm{K}$ (table 1).

Prevention of experimental foreign body infection by solubilized components from purified cell walls. Since the physicochemical properties of prophylactic factors derived from whole cell lysates indicated that they were possibly cell wall components, we also prepared purified cell walls and solubilized their components by the same enzymatic procedure as described above for whole cell lysis. Control experiments verified that solubilized components from purified cell wall contained no residual antibacterial activity, as could have resulted from incompletely inactivated lysostaphin, nor did they include any Limulus-detectable endotoxin activity. As shown in table 2 , the solubilized cell wall components were effective in preventing experimental infection in $88 \%(n=$ 34 ) of tissue cages challenged with $S$. aureus Wood 46 . This protective activity was rapidly obtained, since a time lag ranging from $5 \mathrm{~min}$ to $3 \mathrm{~h}$ between injection of the solubilized cell wall components and the inoculation of live $S$. aureus showed optimal effects (table 2). Furthermore, it appeared that solubilized cell wall components derived from $S$. aureus Wood 46 were active not only against infection due to the autologous strain but also against infection caused by $S$. aureus Cowan I or S. epidermidis KH II (data not shown).

Three different preparations of chemically purified cell wall components were also tested in the prophylactic model of foreign body infection. The least active of these was purified ribitol teichoic acid, which at $10 \mu \mathrm{g} / \mathrm{ml}$ protected only $30 \%(n=10)$ of the challenged tissue cages (table 2). In contrast, the most active preparation was TCA-purified peptidoglycan, which at $10 \mu \mathrm{g} / \mathrm{ml}$ protected $100 \%$ of the challenged cages $(n=10)$. To exclude a major influence of low levels of teichoic acid, a regular contaminant of TCA-purified peptidoglycan, we also tested the prophylactic activity of teichoic acid-free peptidoglycan, prepared by hydrofluoride treatment of purified cell walls: Injected at $10 \mu \mathrm{g} / \mathrm{ml}$, it protected $83 \%(n=12)$ of the challenged tissue cages (table 2$)$.

Prevention of tissue cage infection and in vivo production of $T N F$. Analysis of TNF activity in tissue cage fluid, assayed by the $\mathrm{L} 929$ cytolytic assay, either before or $2 \mathrm{~h}$ after injection of solubilized components from purified cell walls (the time of inoculation of live $S$. aureus Wood 46), showed a dramatic increase in the levels of this cytokine: TNF titers increased from undetectable before injection to a median of 388 units/ml (range, 190-20,000; $n=10$ ) at $2 \mathrm{~h}$ (figure 1). In contrast, control tissue cage fluids injected with saline showed no significant increase in TNF titers from before injection to $2 \mathrm{~h}$ (figure 1). Among the chemically purified cell

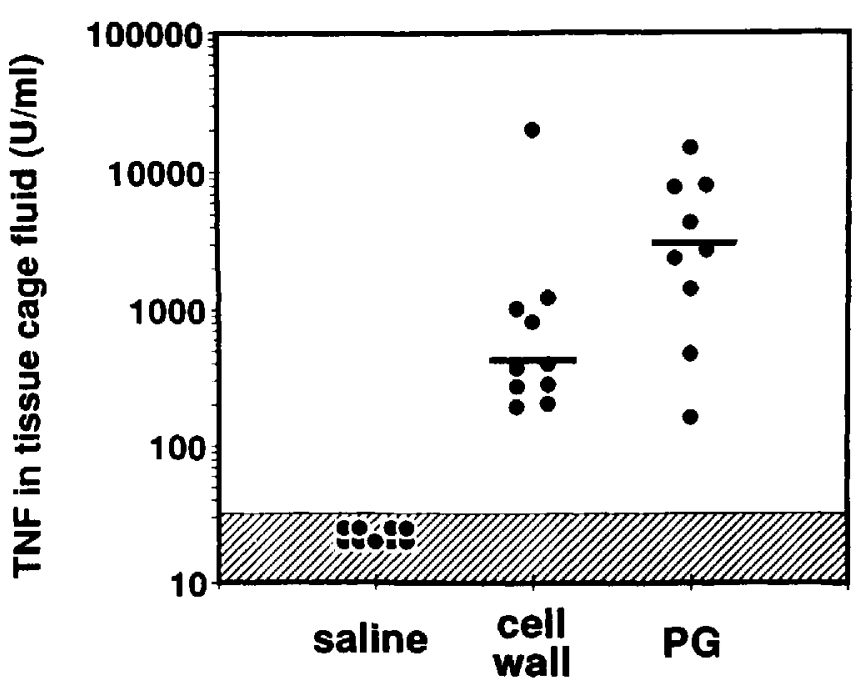

Figure 1. Tumor necrosis factor (TNF) concentrations in tissue cage fluid in guinea pigs (units $/ \mathrm{ml}$ ), measured $2 \mathrm{~h}$ after local injection of either $0.5 \mathrm{ml}$ of saline, purified cell wall components, or purified peptidoglycan (PG). Bars indicate median values. 
wall components, the most consistently active inducer of TNF production in vivo was TCA-purified peptidoglycan, which at $10 \mu \mathrm{g} / \mathrm{ml}$ increased the median TNF titers from $<30$ to 5250 units/ml (range, $470-15,000 ; n=6$ ) in tissue cage fluid within $2 \mathrm{~h}$ (figure l). Similar results were obtained with the teichoic acid-free hydrofluoride-purified peptidoglycan (data not shown). This increase in TNF titers was transitory, since values recorded at $24 \mathrm{~h}$ were $<10 \%$ of the $2-\mathrm{h}$ values (not shown).

Prevention of tissue cage infection by purified murine $r T N F$. Further experiments were done to evaluate whether purified murine rTNF could substitute for the solubilized bacterial factors in preventing tissue cage infection by $S$. aureus. Initial experiments to determine the optimal quantity and time lag of a prophylactic dose of murine rTNF in tissue cages indicated that 6800 units of the purified cytokine injected $30 \mathrm{~min}$ before inoculation of $10^{2}$ cfu of $S$. aureus Wood 46 gave optimal results; in contrast, higher doses (13,400 and 28,600 units) were poorly effective and possibly toxic, as suggested by the hemorrhagic aspect of tissue cage fluids. Experiments in a total of 6 animals confirmed the good prophylactic effect of 6800 units of murine rTNF, which prevented tissue cage infection in $73 \%$ of the tissue cages $(n=11)$ challenged. Because 3400 units was clearly less effective, protecting only $33 \%$ of 6 tissue cages, this regimen was not further tested. Control experiments verified that murine rTNF incubated in vitro with $S$. aureus Wood 46 exerted no effect on growth or viability of the test strain (data not shown).

Inhibition of bacterial factor-induced protection by antiTNF antibody. To further confirm that protection from experimental foreign body infection by cell wall components was mediated by an increase in TNF in tissue cage fluid, we tried to neutralize this cytokine activity in vivo by anti-TNF antibodies. A dose of $140 \mu \mathrm{g}$ of anti-TNF MAb $2 \mathrm{~A} 5$ (or isotype-matched $\mathrm{MAb}$ without neutralizing activity as a control) in $0.4 \mathrm{ml}$ of PBS was injected into tissue cages $10 \mathrm{~min}$ before injection of a protective dose of peptidoglycan. Treatment with 2A5 MAb, but not with control MAb, significantly blocked in 6 of 8 tissue cages the peptidoglycan-induced protection against experimental infection with $S$. aureus Wood $46(P<.03$, Fisher's exact test with Yates's correction). Eight control tissue cages injected in parallel with $10 \mu \mathrm{g} / \mathrm{ml}$ peptidoglycan alone were all protected from experimental infection with $S$. aureus.

\section{Discussion}

In this report, we showed that staphylococcal cell wall components consistently prevented locally induced staphylococcal experimental foreign body infection and that a significant host response, probably mediated by TNF (cachectin), was involved in such a prophylactic effect. The relationship between enhanced resistance to infectious challenge and lo- cal increase in TNF concentrations was established as follows: TNF titers increased rapidly (within $2 \mathrm{~h}$ ) and significantly after local injection of the prophylactic bacterial factors, injection of purified murine rTNF could substitute for the prophylactic effect of the bacterial factors, and antiTNF antibodies in the tissue cage fluid were antagonistic of the prophylactic effect of bacterial factors.

Our preparations of prophylactically active staphylococcal components were screened either by the Limulus assay or by immunologic and functional assays for the presence of contaminating endotoxin or staphylococcal exotoxins, respectively. It was essential to exclude a significant contribution of these products to the prophylactic effect observed in our model, because endotoxin [7-13] and several staphylococcal exotoxins [33-35] are potent in vitro and in vivo inducers of TNF production and release. Although the staphylococcal strain used to prepare prophylactic components was an active producer of both $\alpha$-toxin [30] and TSST-1 (unpublished data), neither of these exotoxins nor endotoxin could be demonstrated in our preparations of prophylactically active components. We assume that staphylococcal exotoxins were extensively removed from our preparations by the heating and chemical procedures used.

Attempts to explore at a cellular level by which mechanism(s) cell wall components of $S$. aureus induced TNF production in the tissue cage fluid have met with limited success. In vitro incubation of the most active prophylactic components with endotoxin-sensitive murine peritoneal macrophages did not show any significant TNF bioactivity (L929 assay), but small amounts of immunoreactive TNF were found (unpublished data). A possible discrepancy between TNF levels in vivo and the undetectable to low amounts of TNF produced by peritoneal macrophages stimulated with staphylococcal cell wall components could be derived from the results reported by Burchett et al. [36]. TNF production by freshly isolated human monocytes is readily stimulated by LPS. In contrast, the secretion of TNF in response to LPS of tissue macrophages was only moderate in the absence of interferon- $\gamma$. This suggests that the presence of other cells of the immune system, such as T cells, as producers of IFN- $\gamma$ may be crucial to elicit the local response in the in vivo model.

Additional support for the concept of tissue-specific responsiveness of monocytes/macrophages comes from recent studies by C. P. Timmerman and A. Fleer (Utrecht, Netherlands, personal communication) who demonstrated a signifcant in vitro production of TNF by freshly isolated human monocytes incubated with purified peptidoglycan. In contrast, other studies have shown the absence of any significant in vitro TNF production by macrophages incubated with either pneumococcal cell surface components [19] or streptococcal peptidoglycan [20]. Finally, other recent reports suggest that lipoteichoic acid from either $S$. epidermidis [14] or from streptococci [20] may play a significant role in TNF 
production by mononuclear phagocytes. Therefore, it appears likely that the presence of macrophages, fibroblasts, lymphocytes, and polymorphonuclear leukocytes could contribute to local TNF production [7]. A possible target of increased TNF production in tissue cage fluid might well be polymorphonuclear leukocytes, whose bactericidal activity was recently shown to be significantly activated by cytokines released from macrophages and lymphocytes [37].

In conclusion, our experimental model was a useful approach with which to study localized production of TNF and its potential role in host defense against staphylococcal infections. Further studies should focus on how TNF interacts with other components of the cytokine network and with phagocytic cells in vivo and in vitro to better understand defective host defense mechanisms against staphylococcal foreign body infections.

\section{Acknowledgments}

We thank D. Degroote for providing 2A5 MAb, T. O'Reilly for some TNF cytolytic assays, C. Gysler and M. Bento for expert technical assistance, and A. Fleer and C. Ruef for helpful suggestions.

\section{References}

1. Martin MA, Pfaller MA, Wenzel RP. Coagulase-negative staphylococcal bacteremia. Mortality and hospital stay, Ann Intern Med 1989;110:9-16.

2. Vaudaux PE, Lew PD, Waldvogel FA. Host factors predisposing to foreign body infections. In: Bisno AL, Waldvogel FA, eds. Infections associated with indwelling devices. Washington, DC: American Society for Microbiology, 1989:3-26.

3. Noble WC. The production of subcutaneous staphylococcal skin lesions in mice. Br J Exp Pathol 1965;46:254-62.

4. Zimmerli W, Waldvogel FA, Vaudaux $P$, Nydegger UE. Pathogenesis of foreign body infection: description and characteristics of an animal model. J lnfect Dis 1982;146:487-97.

5. Zimmerli W, Lew PD, Waldvogel FA. Pathogenesis of foreign body infection. Evidence for a local granulocyte defect. J Clin Invest 1984:73:1191-1200.

6. Vaudaux P, Lerch P. Nydegger UE, Huggler E. Waldvogel FA. Prevention of Staphylococcus aureus foreign body infection by an autologous bacterial lysate [abstract 109]. In: Program and abstracts of the 25th Interscience Conference on Antimicrobial Agents and Chemotherapy (Minneapolis). Washington. DC: American Society for Microbiology, 1985.

7. Dinarello CA, Mier JW. Lymphokines. N Engl J Med 1987;31 7:9405.

8. Beutler B. Cerami A. Cachectin: more than a tumor necrosis factor. $\mathrm{N}$ Engl J Med 1987:316:379-85.

9. Parant MA. Parant FJ. Chedid LA. Enhancement of resistance to infections by endotoxin-induced serum factor from Mvcobacterium bovis BCG-infected mice. Infect Immun 1980;28:654-9.

10. Havell EA. Production of tumor necrosis factor during murine listeriosis. J Immunol 1987:139:4225-31

11. Kindler V. Sappino AP, Grau GE, Piguet PF, Vassalli P. The inducing role of tumor necrosis factor in the development of bactericidal granulomas during BCG infection. Cell 1989;56:731-40.

12. Sherry B, Cerami A. Cachectin/tumor necrosis factor exerts endocrine, paracrine and autocrine control of inflammatory responses. $\mathbf{J}$ Cell Biol 1988;107:1269-77.

13. Michie HR, Manogue KR. Spriggs DR, et al. Detection of circulating tumor necrosis factor after endotoxin administration. N Engl J Med 1988;318:1481-6.

14. Wakabayashi G, Gelfand JA, Jung WK, Conolly RJ, Burke JF, Dinarello CA. Staphylococcus epidermidis induces complement activation. tumor necrosis factor and interleukin- 1 , a shock-like state and tissue injury in rabbits without endotoxemia. J Clin Invest 1991;87:192535 .

15. Endres S, Ghorbani R, Lonneman G, van der Meer JWM, Dinarello $C$ Measurement of immunoreactive interleukin-Ibeta from human mononuclear cells: optimization of recovery, intrasubject consistency, and comparison with interleukin-lalpha and tumor necrosis factor. Clin Immunol Immunopathol 1988;49:424-38.

16. Schindler R, Mancilla J, Endres S, Ghorbani R, Clark SC. Dinarello CA. Correlations and interactions in the production of interleukin- 6 (IL-6), IL-I, and tumor necrosis factor (TNF) in human blood mononuclear cells: IL-6 suppresses IL-I and TNF. Blood 1990;75:40-7.

17. Mathison JC, Virca GD. Wolfson E. Tobias PS, Glaser K, Ulevitch RJ. Adaptation to bacterial lipopolysaccharide controls lipopolysaccharide-induced tumor necrosis factor production in rabbit macrophages. J Clin Invest 1990:85:1108-18.

18. Ferrante A. Staugas REM, Rowan-Kelly B, et al. Production of tumor necrosis factors alpha and beta by human mononuclear leukocytes stimulated with mitogens, bacteria, and malarial parasites. Infect Immun 1990:58:3996-4003.

19. Riesenfeld-Orn I, Wolpe S, Garcia-Bustos JF, Hoffmann MK, Tuomanen E. Production of interleukin-I but not tumor necrosis factor by human monocytes stimulated with pneumococcal cell surface components. Infect Immun 1989:57:1890-3.

20. Usami H, Yamamoto A. Yamashita W, et al. Antitumour effects of streptococcal lipoteichoic acids on Meth A fibrosarcoma. Br J Cancer $1988 ; 57: 70-3$

21. Ryden C, Rubin K, Speziale P, Höök M, Lindberg M, Wadström T Fibronectin receptors from Staphylococcus aureus. J Biol Chem $1983 ; 258: 3396-401$.

22. Schleifer H, Kandler O. Zur chemischen Zusammensetzung der Zellwände des Streptokokken. 1. Zur aminosäuresequenz des Mureins von $S$. thermophilus and $S$. faecalis. Arch Mikrobiol 1967:57:335-64.

23. Peterson PK, Wilkinson BJ, Kim Y, et al. The key role of peptidoglycan in the opsonization of Staphylococcus aureus. J Clin Invest 1978;61:597-609.

24. Baddiley J, Buchanan JG, Rajbhandary UL, Sanderson AR. Teichoic acid from the walls of Staphylococcus aureus $\mathrm{H}$. Structure of the $\mathrm{N}$ acetylglucosaminylribitol residues. Biochem J 1962;82:439-48.

25. Chen PS, Toribara TY, Warner H. Microdetermination of phosphorus. Anal Chem 1956;28:1756-9.

26. Tipper DJ. Berman MF. Structures of the cell wall peptidoglycans of Siaphylococcus epidermidis Texas 26 and Staphylococcus aureus Copenhagen. I. Chain length and average sequence of cross-bridge peptides. Biochemistry 1969:8:2183-91.

27. Anderson AJ, Green RS, Archibald AR. Specific determination of ribitol teichoic acid in whole bacteria and isolated wall of Bacillus subrilis W 23. Carbohydr Res 1977:57:c7-10.

28. Fiedler F. Schäffler MJ, Stackebrandt E. Biochemical and nucleic acid hybridization studies on Brevibacterium linens and related strains. Arch Microbiol 1981:129:85-93.

29. Schliever1 PM. Shands KN. Dan BB, Schmidt GP, Nishimura RD Identification and characterization of an exotoxin from Staphl/acoccus aureus associated with toxic-shock syndrome. J Infect Dis 1981:143:509-16

30. Arbuthnott JP, Gemmill JP, Kent CG, Lyell A. Haemolysin and en- 
zyme patterns of coagulase positive staphylocosci isolated from toxic epidermal necrolysis. Ritter's disease and impetigo contagiosa. J Med Microbiol 1969:2:479-87.

31. Peters G, Locci R. Pulverer G. Microbial colonization of prosthetic devices. II. Scanning electron microscopy of naturally infected catheters. Zentralbl Bakteriol Mikrobiol Hyg 1981;173:293-9.

32. Flick DA. Gifford GE. Comparison of in vitro cytotoxic assays for tumor necrosis factor. J Immunol Methods 1984;68:167-75.

33. Parsonnet J, Gillis ZA. Production of tumor necrosis factor by human monocytes in response to toxic-shock-syndrome toxin-I. J Infect Dis 1988:158:1026-33.

34. Ikejima T. Okusawa S, van der Meer JWM, Dinarello CA. Induction by toxic-shock-syndrome toxin-I of a circulating tumor necrosis factor- like substance in rabbits and of immunoreactive tumor necrosis factor and interleukin-1 from human mononuclear cells. $J$ Infect Dis 1988;158:1017-25.

35. Fast DJ, Schlievert PM, Nelson RD. Toxic shock syndrome-associated staphylococcal and streptococcal pyrogenic toxins are potent inducers of tumor necrosis factor production. Infect Immun 1989;57:291-4.

36. Burchett SK. Weaver WM, Westall JA, Larsen A, Kronheim S. Wilson (B. Regulation of tumor necrosis factor/cachectin and 1l-1 secretion in human mononuclear phagocytes. J Immunol 1988;140:3473-81.

37. Nathan CF. Neutrophils activation on biological surfaces. Massive secretion of hydrogen peroxide in response to products of macrophages and lymphocytes. J Clin Invest 1987;80:1550-60. 